\title{
Climatic FACTORS, ReProductive SuCCESS AND POPULATION DYNAMICS IN THE Montane Vole, MiCRotus MontanUS.
}

\section{AELITA J. PINTER $\uparrow$ DEPARTMENT OF BIOLOGICAL SCIENCES UNIVERSITY OF NEW ORLEANS $\uparrow$ LA}

\begin{abstract}
$\downarrow$ OBJECTIVES
A variety of hypotheses have been proposed to explain multiannual fluctuations in population density ("cycles") of small rodents (for reviews see Finerty 1980, Taitt and Krebs 1985). Doubtless, such cycles - known since antiquity (Elton 1942) - result from an interaction of a multitude of factors. However, the inability of extant hypotheses, alone or in combination, to explain the causality of cycles rests in no small measure with the fact that long-term studies of the phenomenon are notoriously uncommon.
\end{abstract}

The objectives of this project are to continue the long-term study of population dynamics of the montane vole, Microtus montanus, in Grand Teton National Park. Earlier observations (Pinter 1986, 1988 ) indicate that environmental variables might contribute to the population density cycles of these rodents, possibly by influencing their growth and various aspects of their reproduction.

\section{$\downarrow \quad$ MeTHODS}

In 2003 Microtus montanus were livetrapped at two times of the year: the second half of May (spring study period) and mid-July to mid-August (summer study period). Animals were killed with an overdose of Metofane as soon as possible after capture. They were aged using weight, total length and pelage characteristics. Reproductive organs, the spleen and the adrenal glands were collected from all animals and preserved in Lillie's neutral buffered formalin for further histological study. Flat skins were prepared from all animals.

Population density was estimated on the basis of trapping success in a permanent grid (established in 1970). The grid consists of 121 stations placed in a square, $5 \mathrm{~m}$ apart, 11 stations (50 m) on a side. Each station is marked with a stake. Trapping in this grid was performed only during the summer study period. One unbaited Sherman livetrap was set at each station. Additional trapping was carried out in nearby meadows away from the grid to obtain additional females for litter size determination.

During the spring study period trapping was carried out at a number of sites, all of them well removed from the permanent grid. The purpose of this was to leave the grid site as undisturbed as possible since the grid was the major source of information on population density. The main objective of the spring study period was to determine (on the basis of embryo size) the onset of reproduction on a population-wide basis. This information is very important for two major reasons: (1) onset of reproduction in M. montanus in Grand Teton National Park can vary by as much as 40 days among years, and (2) the time at which reproduction begins has significant repercussions on the productivity of the population for the year.

Weather data were obtained from records at the Jackson Lake Dam. Although Moran 5WNW is not a Class A weather station, it is located less than 2 
$\mathrm{km}$ from the permanent grid. Data collected included temperature, precipitation, and the date of complete spring melt-off.

\section{$\downarrow \quad$ RESUlTS AND DISCUSSION}

In 2003 Microtus montanus in all study areas began breeding in early May, about a week earlier than in 2002. Furthermore, litter sizes were $15 \%$ larger than those recorded during the spring study period of 2002 . An early production of large litters has significant repercussions on population dynamics of Microtus montanus. The first litter always matures at an early age and invariably breeds in the year of its birth. Consequently, large first litters add large numbers of breeders (as opposed to merely individuals - Pinter 1986, 1988) to the population, resulting in significant population growth throughout the breeding season.

In 2003 the West continued to experience drought conditions that, paradoxically, were advantageous to the breeding success of Microtus montanus in the spring of 2003. Snow had melted from all the study areas and all melt-water had drained completely, leaving the meadows remarkably dry for this time of the year. Wet springs have a deleterious effect on reproductive success of voles in the spring as flooding of burrows can lead to the demise of that all-important first litter. Consequently, the early onset of breeding, the increase in litter sizes observed during the spring study period of 2003, and the unusually dry spring all presaged an increase in the summer population density.

It was clear at the onset of the summer study period in 2003 that there had, indeed, been a remarkable increase (above densities seen in the summer of 2002) in the population density of montane voles in all study areas. In marginal habitats there was an increase of two orders of magnitude, in optimal habitats it approached four orders of magnitude. This difference was not surprising since in optimal habitats litter sizes were $25 \%$ higher than litter sizes in marginal habitats.

Although there was a significant increase in the population density of Microtus montanus during the summer of 2003, it also became obvious toward the end of the summer study period that reproduction was being severely compromised by the continuing drought. Vegetation in all study areas was unusually short and dry. Only animals born after the first week in July appeared to be breeding; growth and sexual maturation in animals born after that time was severely delayed. In fact, the dynamics of growth and maturation in montane voles were strongly reminiscent of the pattern observed in the summer of 1988 (Negus, Berger and Pinter 1992), one of the driest summers on record in northwestern Wyoming.

There was also a decrease in predation pressure on montane voles during the summer of 2003. No weasels (Mustela spp) entered the live-traps during the entire 2003 study period. This was somewhat unusual since ordinarily at least a few weasels are trapped in the early part of August when the young of the year begin more extensive explorations.

The summer study period of 2003 was also noteworthy for the exceptionally high incidence of parasitism by larval Cuterebra. Nine percent of all Microtus were parasitized, with several hosts carrying more than one larva. Equally noteworthy, however, was the apparently successful defense that had been mounted in virtually every case. As in previous years, parasitism was observed in some study areas while it was totally absent in others; furthermore, this was a consistent pattern - areas from which parasitism by Cuterebra had never been reported in other years were also devoid of such parasitism in the 2003 study period.

\section{$\downarrow \quad$ CONCLUSIONS}

In 2003 there was a dramatic rise in population densities of Microtus montanus in Grand Teton National Park. This increase could be attributed to an early onset of breeding, large litter sizes, a dry spring and reduced predation pressure. As expected, the rise in animal numbers was most dramatic in optimal habitats. However, toward the end of the summer drought conditions apparently curtailed reproductive success of montane voles. Parasitism by Cuterebra did not appear to have affected montane voles as virtually all parasitized animals had mounted a successful defense.

\section{ACKNOWLEDGMENTS}

I gratefully acknowledge the availability of the facilities at the University of Wyoming-National Park Service Research Center and the enthusiastic support of the Research Center staff without which it would have been impossible to accomplish this work. I am particularly grateful to the Steering Committee of the UW-NPS Research Center and to the National Park 
Service for their cognizance of the fact that the understanding of microtine cycles can be gained only from long-term studies in undisturbed habitats.

\section{LITERATURE CITED}

Elton, C. S. 1942. Voles, mice and lemmings. Clarendon Press, Oxford. 496 pp.

Finerty, J. P. 1980. The Population Ecology of Cycles in Small Mammals. Mathematic Theory and Biological Fact. Yale Univ. Press, New Haven. 234 pp.

Negus, N. C., P. J. Berger and A. J. Pinter. 1992. Phenotypic plasticity of the montane vole (Microtus montanus) in unpredictable environments. Can. J. Zool. 70:2121-2124.
Pinter, A. J. 1986. Population dynamics and litter size of the montane vole, Microtus montanus. Can. J. Zool. 64:1487-1490.

Pinter, A. J. 1988. Multiannual fluctuations in precipitation and population dynamics of the montane vole, Microtus montanus. Can. J. Zool. 66:2128-2132.

Taitt, M. J. and C. J. Krebs. 1985. Population dynamics and cycles. In: Biology of New Microtus. R. H. Tamarin, ed. Spec. Pub. Amer. Soc. Mammal. 8:567-620, 